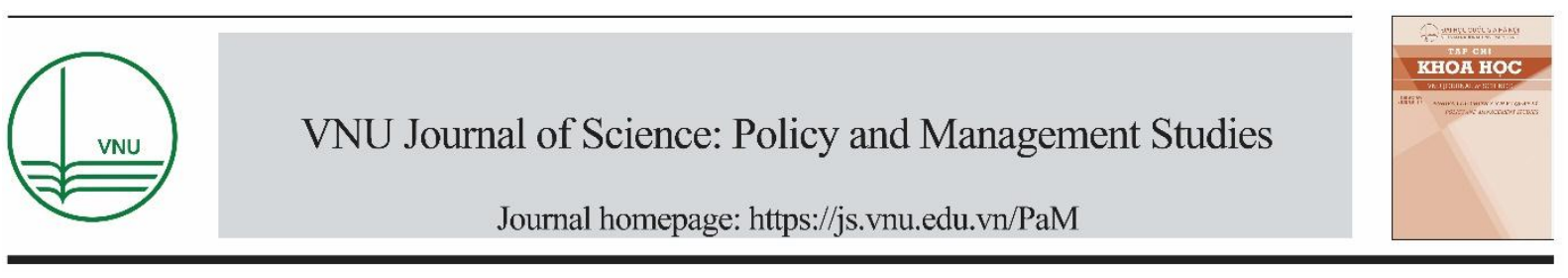

Original Article

\title{
Ethnic Minorities’ Migration Trends in Central Highland
}

\author{
Ha Viet Hung* \\ Institute for Sociology and Development, Ho Chi Minh National Political Academy, \\ 135 Nguyen Phong Sac, Cau Giay, Hanoi, Vietnam
}

Received 11 July 2019

Revised 11 September 2019; Accepted 16 September 2019

\begin{abstract}
Migration of ethnic minorities in Central Highland region is a big concern of the policymakers as well as the social researchers. Based on the analysis of data from two Vietnam internal migration surveys taken in 2004 and 2015, the Central Highland had been a destination area for a majority of ethnic minorities' rural-rural migrants. The study shows that the size of voluntary migrants came to the Central Highland region is strongly decreasing over the last five years. In contrast, there appeared an increasing group of voluntary migrants come out from the Central Highland to other regions, especially the North-East, looking for a job, income-earning for their households. The number of rural-urban migrants is increasing while the number of rural-rural migrants is decreasing among the ethnic minorities' migrants. The share of temporary migrants is becoming dominant over the permanent ones in both in- and out-migration in the Central Highland region. The main purpose of the movement is seeking a job, income earning. By analyzing the existing data sets, it shows a significant impact of migrants' education on their decision of movement. The study results may contribute to estimate the migration trend and serve as evidence for the ethnic minorities' policymaking on the period from now to 2030.
\end{abstract}

Keywords: Ethnic minorities, Voluntary migration, Labour migration, Central Highland.

\footnotetext{
* Corresponding author.

E-mail address: hunghv135@gmail.com
}

_https://doi.org/10.25073/2588-1116/vnupam.4187 


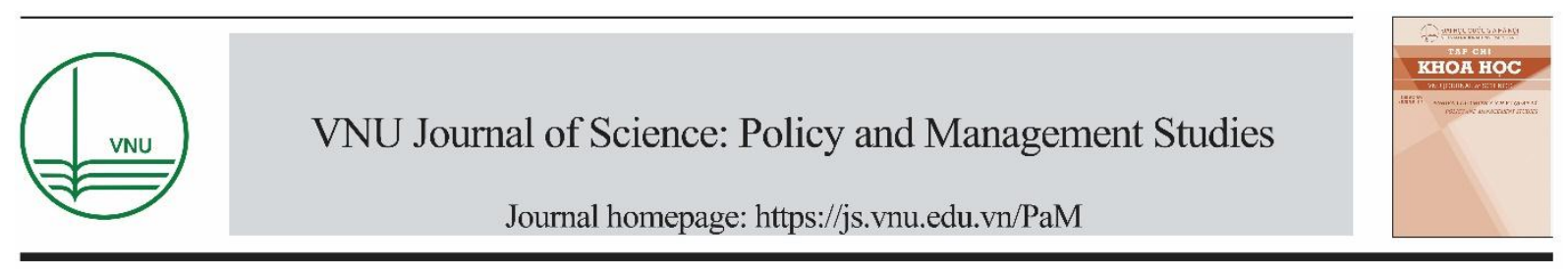

\title{
Thực trạng và xu hướng di cư của đồng bào dân tộc thiểu số ở Tây Nguyên
}

\author{
Hà Việt Hùng* \\ Viện Xã hội học và Phát triển, Học viện Chính trị Quốc gia Hồ Chí Minh, \\ 135 Nguyến Phong Sắc, Cầu Giấy, Hà Nội, Việt Nam \\ Nhận ngày 11 tháng 7 năm 2019 \\ Chỉnh sửa ngày 11 tháng 9 năm 2019; Chấp nhận đăng ngày 16 tháng 9 năm 2019
}

\begin{abstract}
Tóm tắt: Di cư của đồng bào các dân tộc thiểu số ở Tây Nguyên diễn biến như thế nào là mối quan tâm lớn của các nhà hoạch định chính sách và nghiên cứu xã hội. Từ kết quả phân tích số liệu hai cuộc điều tra di dân Việt Nam 2004 và 2015, Tây Nguyên là một địa bàn di cư đến của một bộ phận lớn những người di cư DTTS từ các vùng nông thôn. Kết quả khảo sát của Đề tài cho thấy quy mô số người di cư tự do, là đồng bào DTTS, tới Tây Nguyên đã có xu hướng giảm mạnh trong 5 năm gần đây. Xuất hiện luồng di cư tự do với quy mô ngày càng tăng từ Tây Nguyên tới các vùng khác, trong đó chủ yếu tới Đông Nam Bộ, để có việc làm, tăng thu nhập cho hộ gia đình. Số người di cư theo luồng nông thôn-đô thị ngày càng tăng trong khi số người di cư theo luồng nông thôn-nông thôn ngày càng giảm. Tỷ trọng những người di cư tạm thời ngày càng chiếm ưu thế so với những người di cư lâu dài ở cả hai luồng di cư đến và đi từ Tây Nguyên. Tìm việc làm, tăng thu nhập là mục tiêu chính của những người di cư. Có một số khác biệt đáng kể trong việc lựa chọn di cư giữa các nhóm DTTS tại chỗ với các nhóm DTTS khác. Kết quả phân tích các bộ số liệu cho thấy tác động mạnh của yếu tố học vấn tới bức tranh di cư của đồng bào DTTS. Kết quả nghiên cứu có thể góp phần cho dự báo về xu hướng di cư và làm cơ sở cho việc hoạch định chính sách dân tộc trong giai đoạn từ nay đến năm 2030 .
\end{abstract}

Từ khóa: Dân tộc thiểu số, Di cư tự do, Di cư lao động, Tây Nguyên.

\section{Giới thiệu}

Từ giữa những năm 1980x, khi đất nước bước vào công cuộc đổi mới, bên cạnh các hình thức di cư theo kế hoạch của Nhà nước là chủ yếu, hình thức di cư tự do cũng bắt đầu phát triển.
Những sự dịch chuyển dân cư này nằm ngoài kế hoạch của Nhà nước và liên quan tới những tác động của quá trình đổi mới, một quá trình chuyển đổi từ nền kinh tế tập trung sang nền kinh tế theo định hướng thị trường. Những quy định mới về pháp luật đã làm giảm nhẹ một số điều kiện mà

\footnotetext{
*Tác giả liên hệ.

Địa chi email: hunghv135@gmail.com

https://doi.org/10.25073/2588-1116/vnupam.4187
} 
trước đây vẫn hạn chế sự di chuyển của người dân, như là xóa bỏ hệ thống bao cấp liên quan chặt chẽ với việc đăng ký hộ khẩu của gia đình và áp dụng cơ chế khoán cho hộ gia đình trong sản xuất nông nghiệp. Trong bối cảnh mới, người nông dân không còn bị bó buộc với ruộng đồng nữa và bắt đầu hình thành thị trường đất đai, từ đó cho phép người nông dân linh hoạt hơn khi di chuyển sau khi chuyển nhượng hoặc cho thuê lại đất đai của họ [1].

Từ đầu những năm 1990x, cùng với quy mô di cư ngày càng tăng lên, xã hội có thể chứng kiến tốc độ phát triển nhanh hơn của khu vực đô thị ở nước ta. Di cư nông thôn - đô thị là một trong những yếu tố chính làm khu vực đô thị phát triển mạnh mẽ. Hiện nay tỷ trọng dân số đô thị ở nước ta mới chiếm khoảng $35 \%$, tỷ trọng này đang còn khá thấp so với quy mô dân số đô thị trung bình của khu vực Đông Nam Á và ở châu Á nói chung [2]. Quá trình công nghiệp hóa, đô thị hóa đang được tiếp tục đẩy mạnh, di cư nông thôn - đô thị sẽ còn tiếp tục tăng lên trong giai đoạn từ nay đến 2030. Nếu như trong những năm $70 \mathrm{x}$ và $80 \mathrm{x}$, hai hình thái di cư chính ở nước ta là di cư đô thị-nông thôn và di cư nông thônnông thôn, thì từ những năm 1990x đến nay, hai hình thái di cư chính ở nước ta là di cư nông thôn-đô thị và di cư nông thôn-nông thôn. Các đô thị lớn ở vùng đồng bằng sông Hồng và Đông Nam Bộ là những điểm đến chủ yếu của dòng di cư nông thôn-đô thị. Trong khi đó, các tỉnh Tây Nguyên là những điểm đến chủ yếu của dòng di cư nông thôn-nông thôn ở nước ta trong vòng 30 năm vừa qua $[3,4]$.

Đó là bức tranh chung về các động thái di cư ở nước ta. Thực trạng di cư của các dân tộc thiểu số nói chung và ở vùng Tây Nguyên như thế nào vẫn đang là mối quan tâm lớn của các nhà hoạch định chính sách và các nhà nghiên cứu xã hội.

\section{Các loại hình di cư}

Có nhiều loại hình di cư khác nhau. Phân loại theo mục đích di cư, có thể phân chia thành các loại hình di cư lao động, di cư chữa bệnh, di cư đi học, di cư hôn nhân, v.v... Mục đích của di cư lao động là tìm được việc làm tốt hơn để tăng thu nhập và cải thiện sinh kế cho bản thân và gia đình của người lao động.

Phân loại theo thời gian cư trú ở nơi đến, có thể phân chia thành hai loại hình di cư tạm thời và di cư lâu dài. Với loại hình di cư tạm thời, những người di cư không có ý định ở lại lâu dài tại nơi đến. Với loại hình di cư lâu dài thì những người di cư có ý định ở lại lâu dài tại nơi đến. Khác biệt cơ bản nhất giữa di cư tạm thời và di cư lâu dài là không hoặc có việc chuyển đăng ký hộ khẩu thường trú của những người di cư.

Phân loại theo tiêu chí quản lý nhà nước, có thể phân chia thành hai loại hình di cư theo kế hoạch và di cư tự do. Di cư hay di dân theo kế hoạch là một loại hình di cư được các cơ quan hành chính của Nhà nước trực tiếp tổ chức. $\mathrm{Di}$ cư tự do là loại hình di cư mà người dân và gia đình của họ tự tổ chức di cư hay tự di chuyển nơi cư trú/làm việc. Việc di chuyển tự do này có thể được Nhà nước khuyến khích hoặc không khuyến khích.

Phân loại theo tiêu chí nông thôn/đô thị, có bốn loại hình hay luồng di cư, đó là: di cư nông thôn-nông thôn; di cư nông thôn-đô thị; di cư đô thị-nông thôn; và di cư đô thị-đô thị.

\section{Di cư dân tộc thiểu số ở Việt Nam}

Kết quả phân tích số liệu hai cuộc điều tra di dân nội địa Việt Nam 2004 và 2015 của nhóm nghiên cứu cho biết, tỷ trọng số người di cư là đồng bào dân tộc thiểu số (DTTS) chiếm 9,7 và $9,4 \%$ trong tổng số những người di cư trong vòng 5 năm tính từ thời điểm điều tra. Nếu tính riêng khu vực nông thôn, thì tỷ trong số người di cư DTTS chiếm tương ứng là 12,1 và $12,0 \%$. Theo số liệu của Tổng điều tra dân số 2009, tỷ trọng dân số DTTS chiếm 14,3\%. Như vậy, trong so sánh mức độ di cư theo tiêu chí dân tộc, đồng bào DTTS di cư ít hơn so với đồng bào dân tộc Kinh cả ở vùng nông thôn và ở vùng đô thị. Xu hướng di cư này hầu như ít biến đổi trong giai đoạn từ đầu những năm 2000x đến nay.

Phân tích theo tiêu chí nông thôn/đô thị cho biết, trong tổng số người di cư được khảo sát của 
cả nước trong hai cuộc điều tra trên, tỷ trọng số người di cư từ các vùng nông thôn chiếm tương ứng là 67,8 và $55,8 \%$. Kết quả phân tích riêng với nhóm di cư DTTS tương ứng là 96,1 và $71,2 \%$. Như vậy xu hướng di cư chung của các nhóm dân số trong cơ cấu di cư, bao gồm cả các nhóm DTTS, là tỷ trọng di cư ở các vùng nông thôn đều giảm đi. Mức độ giảm của các nhóm DTTS là 24,9 điểm phần trăm so với mức độ giảm chung chỉ có 12 điểm phần trăm.

Kết quả phân tích các số liệu điều tra di dân Việt nam 2004 cho thấy, một tỷ lệ lớn những người tham gia dòng di cư nông thôn-nông thôn từ các địa phương trong cả nước tới Tây Nguyên là đồng bào các dân tộc thiểu số. Trong số những người di cư DTTS từ các vùng nông thôn, có $81,3 \%$ số người đã lựa chọn nơi đến là vùng Tây Nguyên. Việc phân tích các số liệu điều tra di dân Việt nam 2015 cho kết quả tương ứng là $30,4 \%$. Từ so sánh số liệu của hai cuộc điều tra, có thể nhận xét là trong giai đoạn hơn 10 năm từ 2004-2015, cơ cấu những người di cư từ nông thôn theo tiêu chí dân tộc hầu như không có biến đổi nào, nhưng cơ cấu những người di cư DTTS theo tiêu chí các địa bàn nơi đến đã có nhiều biến đổi. Tỷ lệ số người có lựa chọn tới Tây Nguyên giảm hơn $50 \%$ so với khoảng 10 năm trước đó.

Phân tích theo tiêu chí nông thôn/đô thị với số liệu của cả hai cuộc điều tra di dân 2004 và 2015, có thể thấy, trong số những người di cư DTTS, có gần $90 \%$ số người tham gia luồng di cư nông thôn-nông thôn; và chỉ có khoảng $10 \%$ số người tham gia luồng di cư nông thôn-đô thị. Từ kết quả phân tích số liệu của hai cuộc điều tra di dân trên phạm vi cả nước có thể thấy, quy mô những người di cư DTTS có xu hướng tăng lên ở cả hai luồng di cư nông thôn-đô thị và nông thôn-nông thôn. Tuy nhiên, cơ cấu các địa bàn di cư đến của đồng bào DTTS trong luồng di cư nông thôn-nông thôn đã có những biến đổi quan trọng. Tỷ lệ số người di cư DTTS có lựa chọn tới Tây Nguyên đã giảm rất nhiều. Đa số những người di cư DTTS có thể đã lựa chọn di cư nội vùng/nội tỉnh thay vì đi tới Tây Nguyên như trước đây.

Từ tiếp cận "lực đẩy và lực hút", đối với đồng bào các dân tộc thiểu số ở các tỉnh phía
Bắc, thì Tây Nguyên là vùng đất hứa hẹn với nguồn lực đất đai rừng và thiên nhiên, đất đai thổ nhưỡng màu mỡ, khí hậu thuận lợi để canh tác. Đây là những yếu tố hút người dân tộc thiểu số từ các vùng nghèo, thiếu đất canh tác, thiếu việc làm và thu nhập thấp ở các tỉnh miền núi phía Bắc và Bắc Trung Bộ di chuyển đến Tây Nguyên làm ăn sinh sống, định cư và phát triển [5]. Đa số đồng bào các dân tộc thiểu số tham gia dòng di cư nông thôn-nông thôn vào Tây Nguyên như nêu trên mà ít tham gia vào dòng di cư nông thôn-đô thị là bởi vì đa số người di cư DTTS, từ các vùng nông thôn, có thể chỉ có trình độ văn hóa tương đối thấp và chưa qua đào tạo nghề do đó họ rất khó cạnh tranh được việc làm ở các khu vực đô thị.

Bảng 1. Trình độ văn hóa của người di cư DTTS từ nông thôn

\begin{tabular}{lcl}
\cline { 1 - 1 } $\begin{array}{c}\text { Số liệu } \\
\text { điều tra }\end{array}$ & $\begin{array}{c}\text { Chưa tôt nghiệp } \\
\text { THCS trở xuông, \% }\end{array}$ & \\
& Cả nước & $\begin{array}{l}\text { Tới Tây } \\
\text { Nguyên }\end{array}$ \\
\hline 2004 & 54,0 & 63,0 \\
2015 & 33,1 & 68,3 \\
\hline
\end{tabular}

Bảng 1 trình bày kết quả phân tích số liệu về trình độ văn hóa của những người di cư DTTS từ các vùng nông thôn. Có thể thấy, nhóm di cư DTTS tới Tây Nguyên có trình độ văn hóa tương đối thấp so với những người di cư DTTS từ các vùng nông thôn nói chung. Năm 2015, tỷ lệ số người di cư DTTS tới Tây Nguyên chưa tốt nghiệp trung học cơ sở (THCS) trở xuống cao hơn gấp đôi so với tỷ lệ chung của cả nước. Kết quả phân tích các số liệu điều tra còn cho biết, tỷ lệ mù chữ trong số những người di cư DTTS tới Tây Nguyên theo số liệu hai cuộc điều tra 2004 và 2015 tương ứng là 27,2 và $12,9 \%$. Một mặt có thể thấy trình độ văn hóa chung của người lao động ở nước ta sau 10 năm đã được nâng lên. Từ mặt khác, những người di cư có trình độ văn hóa thấp hơn có xu hướng lựa chọn tới Tây Nguyên nhiều hơn.

Các số liệu của hai cuộc điều tra di dân 2004 và 2015 mới chỉ có thể cho biết một bức tranh 
tương đối chung về di cư của DTTS, từ đó có thể thấy vùng Tây Nguyên là một địa bàn di cư đến của một bộ phận lớn những người di cư DTTS từ các vùng nông thôn. Các số liệu của hai cuộc điều tra này chưa cho phép hiểu đầy đủ về thực trang và xu hướng di cư của các nhóm dân tộc, bao gồm cả DTTS tại chỗ ở Tây Nguyên như thế nào?

\section{Di cư tự do tới Tây Nguyên}

Một số kết quả nghiên cứu mới về di cư của đồng bào dân tộc thiểu số ở các tỉnh miền núi phía Bắc cho thấy, một đặc điểm lớn của diễn biến di cư từ những năm 1990x đến nay là quy mô và tỷ trọng số người di cư theo kế hoạch của Nhà nước và do các cơ quan Nhà nước tổ chức thực hiện ngày càng giảm, trong khi quy mô và tỷ trọng số người di cư ngoài kế hoạch/di cư tự do (người di cư chủ động lựa chọn nơi đến) ngày càng tăng [6].

Trong cơ cấu của các luồng di cư tự do, có luồng di cư tự do của một bộ phận đồng bào dân tộc thiểu số ở các tỉnh trung du, miền núi phía Bắc vào các tỉnh Tây Nguyên. Theo một báo cáo của Chính phủ [7], từ năm 2005 đến nay có 66.738 hộ di cư tự do tới 3 vùng Tây Bắc, Tây Nguyên và Tây Nam Bộ. Trong đó, giai đoạn 2005-2012 là 56.237 hộ, giai đoạn 2013-2017 là 10.501 hộ. Chia theo địa bàn, ở Tây Bắc có 5811 hộ (8,7 \%); ở Tây Nguyên có 58.846 hộ $(88,2 \%)$ và Tây Nam Bộ có 2081 hộ (3,1 \%). Như vậy, đa số dân di cư tự do đã lựa chọn Tây Nguyên là điểm đến của họ. Ước tỉnh tỷ lệ số đồng bào DTTS chiếm khoảng $50 \%$ trong số người di cư tự do tới Tây Nguyên.

Phân tích các số liệu nêu trên có thể thấy, quy mô luồng di cư tự do tới Tây Nguyên đã có xu hướng giảm mạnh trong 5 năm gần đây. Số lượng người di cư tự do đển Tây Nguyên đã giảm từ 3-6 lần. Đồng bào DTTS chiếm từ 35-50\% số người di cư tự do tới các tỉnh Tây Nguyên. Có thể nhận xét là, trong khi quy mô di cư nói chung vẫn đang tăng lên trong quá trình tiếp tục đầy mạnh công nghiệp hóa, đô thị hóa, thì loại hình di cư tự do theo luồng nông thôn-nông thôn tới Tây Nguyên đang có xu hướng giảm mạnh. Kết quả này cũng phù hợp với những kết quả phân tích số liệu của hai cuộc điều tra di dân 2004 và 2015 đối với di cư DTTS như đã nêu ở trên.

Trong công tác quản lý nhà nước, việc có một bộ phận lớn người dân di cư tự do tới các tỉnh Tây Nguyên là một mối quan tâm lớn của chính quyền địa phương các cấp trong nhiều năm qua. Việc di chuyển cả hộ gia đình tới địa bàn cư trú mới và có ý định ở lại lâu dài đã và đang gây những khó khăn rất lớn cho các địa phương liên quan trong việc bố trí, sắp xếp đất ở và đất sản xuất, cũng như trong thực hiện công tác bảo vệ diện tích rừng tự nhiên đang còn rất ít hiện nay. Cũng theo Báo cáo của Chính phủ, hiện nay có khoảng 24.000 hộ với gần 100.000 người chưa được ổn định nơi cư trú khi tới các tỉnh Tây Nguyên trong những năm vừa qua [7].

Trong các nghiên cứu về di cư và di cư tự do, các nhà nghiên cứu chủ yếu mới đề cập tới nhóm di cư lâu dài mà chưa quan tâm thỏa đáng tới nhóm di cư tạm thời, trong đó chủ yếu là di cư lao động. Kết quả nghiên cứu bước đầu của Đề tài này ${ }^{1}$ cho thấy, quy mô số lượng những người di cư tạm thời đang ngày càng chiếm ưu thế so với những người di cư lâu dài ở trong phạm vi cả nước cũng như ở các tỉnh Tây Nguyên.

\section{Di cư lao động tới Tây Nguyên}

Ở phần trên, từ góc độ di cư đến Tây Nguyên, đã đề cập tới hình thức di cư tự do lâu dài vào định cư ở Tây Nguyên. Bên cạnh đó, cần chú ý tới hình thức di cư tự do tạm thời của người lao động tới vùng đất cao nguyên này. Hình thức di cư tự do này chủ yếu liên quan tới mùa vụ hái cà phê và tiêu ở các tỉnh Tây Nguyên. Kết quả khảo sát của Đề tài cho thấy, trong những năm gần đây số lượng người di cư lao động mùa vụ, chủ yếu từ các tỉnh ven biển miền Trung, tới Tây Nguyên đã giảm khoảng một nửa. Nguyên nhân

\footnotetext{
$\overline{1}$ Đề tài "Di dân các dân tộc thiểu số - những vấn đề đặt ra và giải pháp”, Mã số CTDT.09-17/16-20.
} 
của chiều hướng giảm sút này là (i) giá nông sản các loại như cà phê và tiêu những năm gần đây bị giảm mạnh, các hộ gia đình trồng cà phê hay tiêu không có lãi, thậm chí không đủ tiền để trả công thuê lao động từ các địa phương khác tới. Do đó, nhu cầu thuê lao động hái cà phê hay tiêu đã giảm mạnh; (ii) do giá cà phê và tiêu bị giảm nên giá tiền công lao động hái cà phê và tiêu so sánh với 5-7 năm trước đây cũng không thể tăng lên được. Do đó, với người lao động di cư, tiền công lao động như vậy đối với họ không còn hấp dẫn, thậm chí là thấp, không còn dư mang về khi trở về nhà nên phần lớn người lao động di cư mùa vụ không lựa chọn đi tới Tây Nguyên trong những năm gần đây.

Như vậy, quy mô các luồng di cư đến Tây Nguyên, bao gồm cả di cư lâu dài và di cư tạm thời đều giảm mạnh trong vòng 5 năm gần đây. Từ những điều kiện thực tế của Tây Nguyên hiện nay là (i) nguồn đất ở và đất sản xuất có thể khai phá hầu như đã không còn nữa; và (ii) nhu cầu lao động phổ thông trong sản xuất nông nghiệp đang giảm, cho nên, quy mô các luồng di cư đến Tây Nguyên nói chung, và của đồng bào dân tộc thiểu số có thể biến đồi theo xu hướng tiếp tục giảm trong giai đoạn từ nay đến năm 2030.

\section{Di cư lao động từ Tây Nguyên tới vùng khác}

Thực trạng di cư của đồng bào dân tộc thiểu số ở Tây Nguyên có mối liên hệ như thế nào với xu hướng quy mô di cư ngày càng tăng ở nước ta trong quá trình công nghiệp hóa, hiện đại hóa? Những người lao động dân tộc thiểu số có tham gia luồng di cư nông thôn-đồ thị tới vùng Đông Nam Bộ hay các đô thị ở ven biển miền Trung? Có khác biệt nào trong di cư hiện nay giữa đồng bào DTTS tại chỗ với đồng bào DTTS di cư tới Tây Nguyên trong 30 năm qua? Đây là những câu hỏi đặt ra với bài viết nghiên cứu nhằm có câu trả lời đầy đủ về thực trạng và xu hướng di cư các DTTS ở Tây Nguyên.

Với một địa bàn cụ thể luôn có hai luồng di cư đến và di cư đi, với địa bàn 5 tỉnh Tây Nguyên cũng như vậy. Kết quả khảo sát tại Kon Tum và
Đăk Lăk cho thấy, quy mô số lượng người di cư lao động từ Tây Nguyên đi các vùng khác, chủ yếu là tới Đông Nam Bộ đang có xu hướng tăng lên trong những năm gần đây. Ước tính số người lao động hàng năm đi các vùng khác từ Tây Nguyên khoảng trên dưới 100.000 người, chiếm khoảng 2-3\% dân số trong độ tuổi lao động ở Tây Nguyên. Cả người Kinh và dân tộc thiểu số đều tham gia luồng di cư lao động này. Tuy nhiên, đồng bào các dân tộc thiểu số tại chỗ như $\mathrm{Ba} \mathrm{Na}$, Ê Đê ... ít đi làm ở các vùng khác so với dân tộc Kinh và các dân tộc thiểu số khác (Tày, Nùng, Thái...).

Nhóm nghiên cứu đã thu thập số liệu thống kê về một số đặc điểm kinh tê-xã hội của 600 người dân trong độ tuổi lao động ở 8 xã của hai tỉnh Đăk Lăk và Kon Tum, bao gồm những người không di cư, những người di cư nội tỉnh/nội vùng, và những người di cư tới vùng khác, cụ thể như sau: nhóm không di cư chiếm 44,3\%; nhóm di cư nội vùng/tỉnh/huyện - 3,1\%; và nhóm di cư tới Đông Nam Bộ/Duyên hải miền Trung $-47,2 \%$.

Những số liệu trình bày trong Bảng 2 cho thấy, trong số người lao động di cư đi các vùng khác, thì chủ yếu là tới vùng Đông Nam Bộ. Có thể coi di cư là một chỉ báo của phát triển. Những vùng, địa phương có mức độ phát triển kinh tếxã hội cao hơn đều có nhu cầu về lao động lớn hơn, đặc biệt là các địa phương đang có tốc độ công nghiệp hóa, đô thị hóa nhanh hơn. Những nơi đó thường thu hút một số lượng lớn lao động từ các vùng nông thôn ở các địa phương khác tới. Những số liệu nêu trên cũng có thể cho thấy một bức tranh về tốc độ phát triển còn chậm của các vùng Duyên hải miền Trung và Tây Nguyên so với vùng Đông Nam Bộ.

Một mối quan tâm của nhóm nghiên cứu là liệu có sự khác biệt nào về trình độ văn hóa giữa các nhóm lao động theo tiêu chí dân tộc và theo địa bàn di cư. Kết quả phân tích số liệu thống kê thu được cho thấy, có khác biệt đáng kể về trình độ văn hóa giữa các nhóm dân tộc. Nhóm lao động dân tộc Kinh có số năm đi học trung bình là 9,1 năm; nhóm lao động DTTS tại chỗ - 3,7 năm; và nhóm DTTS khác - 8,3 năm (Biểu đồ 1$)$. 
Bảng 2. Tỷ trọng người lao động theo các địa bàn

\begin{tabular}{llllll}
\hline \multirow{2}{*}{ Địa bàn di cư } & \multicolumn{3}{l}{ Số người lao động } & \multicolumn{2}{c}{ Tỷ trọng, } \\
\cline { 2 - 5 } & $\begin{array}{l}\text { DTTS tại } \\
\text { chỗ }\end{array}$ & $\begin{array}{l}\text { DTTS } \\
\text { khác }\end{array}$ & Kinh & Cộng & \\
\hline Đông Nam Bộ & 0 & 149 & 127 & 276 & 46,7 \\
Duyên hải miền Trung & 0 & 3 & 0 & 3 & 0,5 \\
Nội vùng Tây Nguyên & 0 & 4 & 5 & 9 & 1,5 \\
Nội tỉnh & 0 & 18 & 0 & 18 & 3,0 \\
Nội huyện & 0 & 8 & 0 & 8 & 1,3 \\
Trong xã (không di cư) & 128 & 125 & 13 & 266 & 44,3 \\
Đi xuất khẩu lao động & 3 & 5 & 1 & 9 & 1,5 \\
Khác & 0 & 2 & 0 & 2 & 0,3 \\
\hline
\end{tabular}

Nguồn: số liệu khảo sát của Đề tài

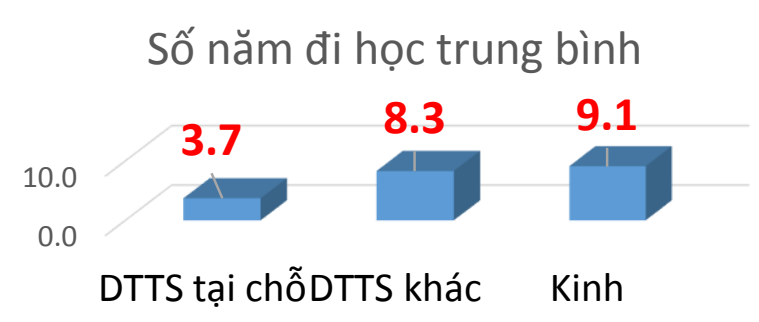

Biểu đồ 1 . So sánh học vấn giữa các nhóm lao động ở Tây Nguyên

Nguồn: Số liệu khảo sát của Đề tài

Biểu đồ 2 trình bày kết quả so sánh trình độ văn hóa giữa các nhóm lao động theo địa bàn di cư. Nhóm di cư ngoài vùng có số năm đi học trung bình cao nhất, từ 9,1-9,8 năm; nhóm di cư nội vùng/tỉnh/huyện có số năm đi học trung bình từ 8,3-9,0 năm; còn nhóm không di cư có số năm đi học trung bình chỉ có từ 3,6-8,1 năm. Kết quả phân tích số liệu này cho thấy có một mối liên hệ tương đối rõ ràng giữa trình độ văn hóa của người lao động và khoảng cách di chuyển trong di cư của họ. Yếu tố học vẩn có tác động rất mạnh tới sự lựa chọn việc làm ở các vùng khác của người di cư lao động ở Tây Nguyên.

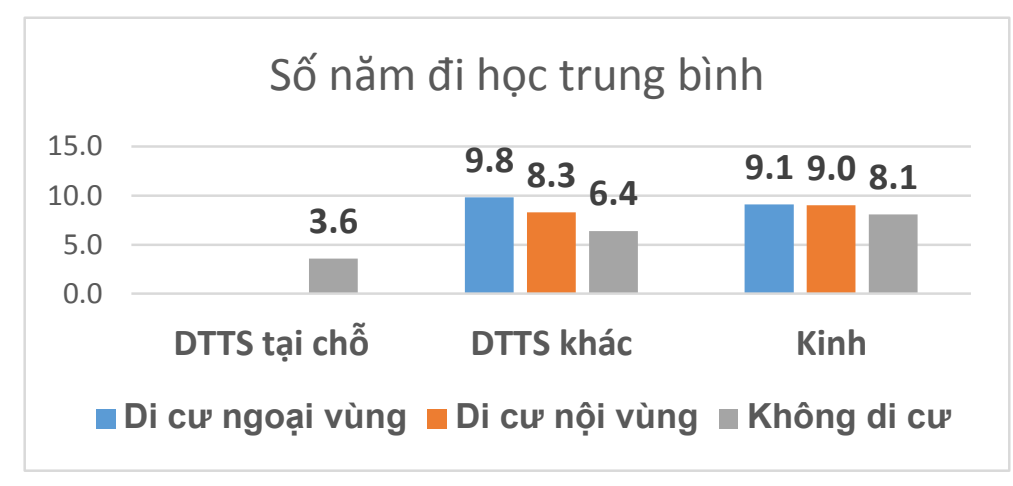

Biểu đồ 2. So sánh học vấn giữa các nhóm lao động theo địa bàn

Nguồn: số liệu khảo sát của Đề tài 
Di cư lao động của người dân Tây Nguyên tới các vùng khác chủ yếu là tới các đô thị/ khu công nghiệp ở vùng Đông Nam Bộ, như Thành phố Hồ Chí Minh, tỉnh Bình Dương hay Đồng Nai. Theo tiêu chí nông thôn/đô thị thì đây là luồng di cư nông thôn-đô thị.

Quá trình công nghiệp hóa, hiện đại hóa là một quá trình biến đổi xã hội tù xã hội nông nghiẹp thành xã họi công nghiệp. Khác biệt cơ bản nhất giữa hai loại hình xã hội này là năng suất lao động. Trong xã hội công nghiệp, nhờ áp dụng các thành tựu tiến bộ khoa học và kỹ thuật, sử dụng máy móc trong sản xuất, con người đã tạo ra năng suất lao động cao gấp hàng trăm/ngàn lần so với xã hội nông nghiệp. Để người lao động có thể tham gia vào quá trình công nghiệp hóa, hiện đại hóa, người lao động phải đi học, và càng ngày càng phải đi học nhiều hơn. Không phải ngẫu nhiên khi chúng ta thấy thực hiện phổ cập giáo dục là bắt buộc đối với mọi người dân trong các xã hội hiện đại [8].

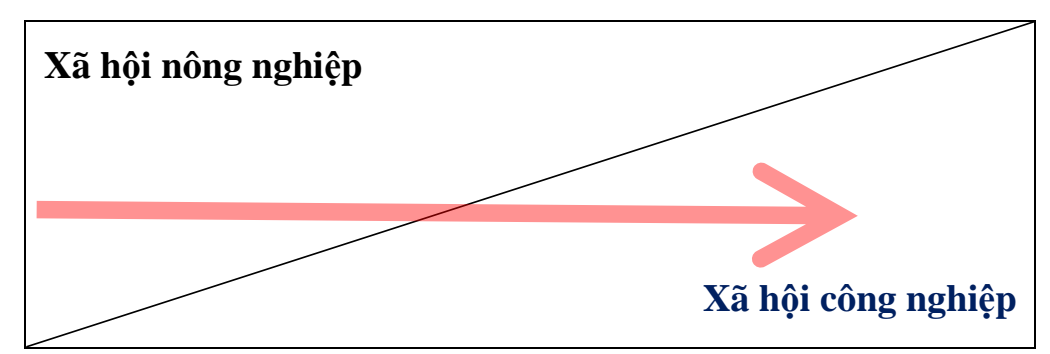

\section{Quá trình hiện đại hóa}

Trong giai đoạn phát triển kinh tế-xã hội hiện nay của đất nước, người lao động ở nông thôn cần có trình độ học vấn tối thiểu là tốt nghiệp trung học cơ sở để từ đó có thể đi tới các khu công nghiệp hay ra đô thị tìm việc làm được thuận lợi hơn. Số liệu trình bày trong Biểu đồ 2 đã cho thấy là số năm đi học trung bình của nhóm người lao động từ Tây Nguyên tới vùng Đông Nam Bộ từ 9,1 - 9,8 năm so với số năm đi học trung bình của nhóm lao động không di cư từ 3,6 - 8,1 năm. Các số liệu thu được cho thấy, số năm đi học trung bình của nhóm người lao động DTTS tại chỗ chỉ có 3,6 - 3,7 năm. Những số liệu khảo sát này cho thây, trình độ văn hóa chung của đồng bào dân tộc thiểu số tại chỗ còn tuoong đối thấp. Yếu tố này tác động đến khả năng lựa chọn huoóng di chuyển tới các khu công nghiệp hay vùng đô thị của nguoòi lao động.

Từ góc độ về yếu tố học vấn của người lao động, có thể giải thích tại sao người lao động DTTS tại chỗ hầu như chưa tham gia luồng di cư lao động tới vùng Đông Nam Bộ. Cũng từ góc độ này, có thể giải thích tại sao một bộ phận lớn người di cư DTTS từ các tỉnh phía Bắc đã tham gia luồng di cư nông thôn-nông thôn vào Tây
Nguyên khi trình độ văn hóa của đa số người di cư là chưa tốt nghiệp phổ thông cơ sở (xem Bảng 1).

\section{Kết luận}

Kết quả phân tích số liệu hai cuộc điều tra di dân Việt Nam 2004 và 2015, cũng như số liệu khảo sát của Đề tài và các số liệu trong Báo cáo của Chính phủ năm 2018, đã cho thấy phần nào bức tranh về quy mô và cơ cấu di cư dân tộc thiểu số hiện nay ở vùng Tây Nguyên. Số lượng người di cư DTTS tới Tây Nguyên để định cư lâu dài hay tạm thời đều giảm mạnh trong 5 năm gần đây. Một bộ phận không nhỏ người lao động DTTS ở Tây Nguyên đã di cư tới các vùng khác, chủ yếu là vùng Đông Nam Bộ, để tìm việc làm, cải thiện thu nhập và đa dạng nguồn sinh kế. Có sự khác biệt trong di cư lao động tới các vùng ngoài Tây Nguyên giữa nhóm DTTS tại chỗ và nhóm DTTS từ các địa phương khác tới Tây Nguyên. Mức độ di cư tới các vùng khác của những người lao động DTTS tại chỗ còn hạn chế so với những người lao động DTTS từ các địa phương khác tới Tây Nguyên. Trình độ văn hóa chung của người lao động DTTS tại chỗ còn 
tương đối thấp so với các nhóm dân số khác ở Tây Nguyên là một nguyên nhân chính để góp phần giải thích về hiện tượng xã hội này.

Trong bối cảnh đất nước đẩy mạnh quá trình công nghiệp hóa, hiện đại hóa và những nỗ lực của chính quyền các cấp nhằm ổn định đời sống của những hộ gia đình di cư tự do tới Tây Nguyên, trong giai đoạn từ nay đến năm 2030, quy mô và số lượng những người di cư tự do tới Tây Nguyên, bao gồm cả đồng bào DTTS, sẽ tiếp tục giảm nhanh. Di cư lao động của đồng bào các nhóm DTTS từ Tây Nguyên tới các đô thị và khu công nghiệp ở nội và ngoại vùng Tây Nguyên sẽ từng bước tăng lên theo mức độ nâng cao mặt bằng trình độ văn hóa chung của người dân Tây Nguyên.

Từ tiếp cận hệ thống, để góp phần ổn định phát triển kinh tế-xã hội cho Tây Nguyên, cần giải quyết vấn đề giáo dục không chỉ đối với đồng bào DTTS tại chỗ ở Tây Nguyên mà còn đối với các vùng đồng bào DTTS ở các tỉnh phía Bắc, những địa bàn là nơi đi của dân di cư tự do. Các tỉnh miền núi, trung du phía Bắc cũng cần phải xây dựng các mục tiêu chính sách giáo dục cho các vùng đồng bào DTTS nhằm nâng cao trình độ học vấn chung của nhóm dân số trong độ tuổi lao động. Giải pháp chính sách này sẽ có ý nghĩa giúp người dân ổn định sinh kế. Khi người lao động có trình độ từ tốt nghiệp THCS trở lên, họ có thể đủ khả năng đi tìm việc làm ở các đô thị hay khu công nghiệp mà không cần rời bỏ quê hương đi tìm nơi cư trú ở các vùng nông thôn khác.

Các mục tiêu của chính sách giáo dục thường là những mục tiêu dài hạn, có thể phải cần 15-20 năm để đưa chỉ số về học vấn của người lao động ở một cộng đồng dân cư từ chỗ điểm xuất phát chưa tốt nghiệp tiểu học đến đích tốt nghiệp trung học cơ sở. Nhưng nếu sinh kế hàng ngày của người dân nghèo không được cải thiện sẽ trực tiếp là nguyên nhân dẫn tới không ổn định xã hội, cản trở phát triển kinh tế-xã hội của địa phương. Do vậy, giải pháp chính sách trong ngắn hạn là các giải pháp nâng cao hiệu quả chương trình mục tiêu quốc gia về giảm nghèo. Cần có các giải pháp nhằm đạt được việc giảm nghèo bền vững. Các vùng dân tộc thiểu số ở Tây Nguyên và các tỉnh miền núi phía Bắc là những địa bàn còn có tỷ lệ số hộ nghèo và cận nghèo rất cao so với mặt bằng xã hội chung của cả nước. Các nguồn lực của chương trình mục tiêu quốc gia về giảm nghèo cần được tập trung dành cho các địa bàn này.

\section{Lời cảm ơn}

Bài báo nghiên cứu là kết quả của Đề tài " $\mathrm{Di}$ dân các dân tộc thiểu số - những vấn đề đặt ra và giải pháp”, Mã số CTDT.09-17/16-20.

\section{Tài liệu tham khảo}

[1] Quỹ dân số Liên Hợp Quốc (UNFPA), Di cư trong nước: Hiện trạng ở Việt Nam, Hà Nội, 2010.

[2] Population Reference Bureau (PRB), World Population Datasheet 2018, https://www.prb.org/2018-world-population-datasheet-with-focus-on-changing-age-structures/ (truy cập ngày 31 tháng 05 năm 2019)

[3] Tổng cục Thống kê và Quỹ dân số Liên Hợp Quốc, Điều tra di cư nội địa quốc gia 2004: Một số kết quả chủ yếu, NXB Thống kê, Hà Nội, 2005.

[4] Tổng cục Thống kê và Quỹ dân số Liên Hợp Quốc, Điều tra di cư nội địa quốc gia 2015: Các kết quả chủ yếu, NXB Thông tấn, Hà Nội, 2016.

[5] Đặng Nguyên Anh, Dân số và di dân trong phát triển bền vững Tây Nguyên, Dự thảo báo cáo đề tài cấp nhà nước $\mathrm{TN} 3 / \mathrm{X} 14$ thuộc Chương trình Tây Nguyên 3 KHCN-TN/11-15, Hà Nội, 2016.

[6] Phan Tân, Trần Thị Giang Thanh, Di cư lao động sang Trung Quốc của người dân khu vực miền núi phía Bắc Việt Nam - nguyên nhân nhìn từ quan điểm di cư quốc tế, Tạp chí Thông tin Khoa học xã hội, số 6 (2019) 29-36.

[7] Bộ Nông nghiệp và Phát triển Nông thôn, Báo cáo tình hình di dân tự do, Hội nghị toàn quốc về di dân tự do tại Buôn Ma Thuột, tỉnh Đăk Lăk, tháng 11 năm 2018.

[8] Rodney Stark, Sociology, Seventh Ed., University of Washington, Wadsworth Publishing Company, 1997. 